\title{
Consideration of Shared Decision Making in Nursing: A Review of Clinicians' Perceptions and Interventions
}

\author{
Noreen M. Clark ${ }^{*}, 1$, Belinda W. Nelson ${ }^{2}$, Melissa A. Valerio ${ }^{3}$, Z. Molly Gong ${ }^{4}$, \\ Judith C. Taylor-Fishwick ${ }^{5}$ and Monica Fletcher ${ }^{6}$
}

\author{
${ }^{I}$ Center for Managing Chronic Disease, University of Michigan, 109 Observatory, Ann Arbor, MI 48109-2029, USA \\ ${ }^{2}$ Center for Managing Chronic Disease, University of Michigan, 109 Observatory, Ann Arbor, Michigan 48109-2029, \\ USA \\ ${ }^{3}$ Health Behavior \& Health Education, University of Michigan School of Public Health, 109 Observatory, Ann Arbor, \\ Michigan 48109-2029, USA \\ ${ }^{4}$ Center for Managing Chronic Disease, University of Michigan, 109 Observatory, Ann Arbor, Michigan 48109-2029, \\ USA \\ ${ }^{5}$ National Respiratory Training Center, Division of Research \& Community Health, P.O Box 5468, Suffolk, VA 23435, \\ USA \\ ${ }^{6}$ National Respiratory Training Center Virginia/Education for Health, The Athenaeum, 10 Church Street, Warwick, \\ CV34 $4 A B, U K$
}

\begin{abstract}
As the number of individuals with chronic illness increases so has the need for strategies to enable nurses to engage them effectively in daily management of their conditions. Shared decision making between patients and nurses is one approach frequently discussed in the literature. This paper reviews recent studies of shared decision making and the meaning of findings for the nurse-patient relationship. Patients likely to prefer to engage in shared decision making are younger and have higher levels of education. However, there is a lack of evidence for the effect of shared decision making on patient outcomes. Further, studies are needed to examine shared decision making when the patient is a child. Nurses are professionally suited to engage their patients fully in treatment plans. More evidence for how shared decision making affects outcomes and how nurses can successfully achieve such engagement is needed.
\end{abstract}

Keywords: Shared decision making, nurse-patient relationship, patient-clinician communication, patient-clinician collaboration, clinical role preference.

\section{INTRODUCTION: THE CONCEPT AND COMPLEXITY OF SHARED DECISION MAKING}

Accompanying the increasing complexity of chronic disease therapies and management strategies has been an interest by nurses in particular and the clinical community in general in shared decision making between patient and health care providers $[1,2]$. It has been noted that health care institutions are being challenged to make high quality and safe services more transparent and efficient and this need requires new models and ways of thinking about how health services are delivered. Shared decision making is often central in calls for improved care because it is thought to promise better health status and patient satisfaction [3]. Nurses are key patient advisors and counselors in practice settings where shared decision making is an increasing expectation. Just how nurses can best carry out their role in this partnership with the patient is not entirely clear. The purpose of this paper is to review recent studies of shared

*Address correspondence to this author at the Center for Managing Chronic Disease, University of Michigan, 109 Observatory, Ann Arbor, MI 481092029, USA; Tel: (734) 763-1457; Fax: (734) 763-9115;

E-mail: nmclark@umich.edu decision making and to consider what findings tell us about the decision making process and the nurse-patient relationship.

The large body of existing literature on the subject suggests that shared decision making is widely discussed in health care. Thistlethwaite et al. [4] describe shared decision making as a process within a patient centered consultation that involves both the patient and clinician discussing management options and agreeing on management decisions in partnership. Butz et al. [5] describe it as a mutual partnership between health care provider and patient. Whitney et al. [6] note that current models of shared decision making portray an empowered patient actively involved in medical choices and assume that patient and clinician reach agreement. Virtually all extant research concerns adult patients. Implications for shared decision making with children and roles nurses and other clinicians assume in such interactions with them have not been examined.

Although shared decision making is a popular concept [3], definitions of it vary greatly. Makoul \& Clayman [7] conducted a review of articles that specifically addressed shared decision making. They found that of the 418 articles 
they examined, 161 had a conceptual definition of shared decision making and, collectively, authors utilized 31 separate concepts to describe it. Two notions appeared in over half the definitions reviewed. These were "patient preferences" and "options". Despite these prevailing concepts, there was no discernible common definition. In a similar vein, Moumjid et al. [8] found among 76 separate articles they reviewed, that seminal papers in which authors provided a clear definition of shared decision making were cited in only one third of the articles and the majority neither provided a precise definition nor used the term consistently throughout the report or study. The variability of shared decision making conceptually is also reflected by the work of Dy [9] who found in the literature over 18 different instruments for measuring it.

To add to understanding of the distinct components of shared decision making, Fraenkel \& McGraw [10] conducted a qualitative study to identify its elements. Although the number of patients was small $(n=26)$ findings appear reasonable when considered in light of the range of definitions provided in the literature. They suggest shared decision making must include: 1) an adequate level of patient knowledge about the condition in question, 2) explicit encouragement of patient participation by the clinician, 3) appreciation of the patient's responsibilities and rights in active decision making, 4) awareness of the options and the implications of the choice made, and 5) sufficient time to engage in collective deliberation.

Whitney et al. [6] suggest that the process of decision making itself should be carefully considered as several steps must be undertaken. These include 1) recognition that a decision can or must be made, 2) identification of possible courses of action, 3) review and listing of pros, cons and other characteristics of each treatment, 4) comparison of options and identification of one as better than others, 5) acceptance or rejection of the choice, resulting in a final choice, 6) authorization of the final choice and 7) implementation. The role of preference is necessary to consider in shared decision making even if there is only one viable choice (one option compared to no action) for treatment. The patient's decisions in such a case are limited but still important.

Patient-health care provider interactions are not without dissonance. Shared decision making is seen as a means to make clinician-patient partnerships stronger and more mutually satisfactory [4]. However, nurses, as well as patients, need to be coached in how to work collaboratively and use evidence in their mutual decision making [2]. This observation underscores the point made by Zoffman et al. [11] that shared decision making may be regarded as an ideal in chronic illness care but is difficult to implement in practice. Enhancing practice and evolving successful models of shared decision making require an understanding of the extant perspectives of nurses and other clinicians and those of patients. These perspectives include their respective roles, as well as, the potential benefits of, and the evident challenges to shared decision making. Such understanding seems important since patients and providers have been shown to have opposing attitudes about shared decision making and often differ in their goals for treatment of the given condition [12].

\section{AIMS, OBJECTIVES AND METHODS}

The aim of this review was to determine the state of the art of shared decision making as a concept receiving considerable attention in clinical nursing. The specific objectives were to determine 1) the perception of nurses and other clinicians and their patients toward shared decision making with patients and 2) patient health outcomes of interventions designed to enhance shared decision making. A search strategy to identify recent and relevant studies published since 2003 was employed. Four sources of articles were searched: PubMed, Medline, ERIC, and Google Scholar. Only reports in the English language were retrieved. Search terms employed included: shred decision making, nurse, patient and clinician communication and collaboration, and clinical role preferences. Eighty articles were initially located. Twenty four employing rigorous study designs (e.g. randomized clinical trials) are included here.

\section{The Patient's Views of Shared Decision Making}

A number of studies illuminate views of patients regarding shared decision making. Table $\mathbf{1}$ presents a summary of recent work. Briel et al. [13] studied 636 ambulatory patients with acute respiratory infections regarding their wish to be involved in health care decisions. They found that almost two thirds of the patients with this acute condition preferred to leave decision making to their clinicians. Patients expressing this choice were more likely to be satisfied with the care they received. Patients who preferred shared decision making tended be younger, better educated and experienced more discomfort from the infection. Caress et al. [14] surveyed 230 adults with a diagnosis of asthma. Fifty-five percent preferred an active role in treatment decision making, $40 \%$ a passive role, and $36 \%$ a collaborative role. Only $34 \%$ of all respondents had attained their preferred role in encounters with clinicians. No strong association between role preference and demographic factors was noted. Kavanaugh et al. [15] conducted focus groups with patients and found most believed that in order to be involved in decision making they needed information and recommendations from the clinician. Deber $e t$ al. [16] studied over 1700 patients with a range of conditions including breast cancer, HIV/AIDS, fractures, etc. Respondents were asked to use the Problem Solving DecisionMaking (PSDM) scale a) in relation to their current health problem and $b$ ) to assess their preferences for shared decision making given a chest pain vignette. The investigators found that over seventy-five percent of respondents preferred to share decision making with their clinician. The next most preferred style of interaction comprised a passive role and least preferred (less than $1 \%$ of respondents) were an autonomous role. Older and less educated patients were more likely to prefer the passive role. Elkin et al. [17] studied 73 older patients with metastatic colorectal cancer. Just over half of these respondents preferred a passive role in interactions with their clinicians. Less than half wanted survival information when discussing treatments and, when this was preferred, women were less likely to wish to be provided general estimates of survival than men. Funk [18] studied older adults residing in long term care facilities $(n=100)$. They found that formal education, a greater number of chronic conditions and greater confidence in the worth of their input were associated with preference for shared decision making. 
Table 1. Views of Patients and Clinicians Regarding Shared Decision Making

\begin{tabular}{|c|c|c|c|}
\hline Study and Investigators & Participants & Measures & Outcomes Under Interventions \\
\hline $\begin{array}{l}\text { Briel, M., Young, J., Tschudi, P., } \\
\text { Hugenschmidt, C., Bucher, H. C., } \\
\text { \& Langewitz, W. (2007) [13] } \\
\text { Shared-decision making in general } \\
\text { practice: Do patients with } \\
\text { respiratory tract infections actually } \\
\text { want it? Swiss Medical Weekly: } \\
\text { Official Journal of the Swiss } \\
\text { Society of Infectious Diseases, the } \\
\text { Swiss Society of Internal Medicine, } \\
\text { the Swiss Society of Pneumology, } \\
\text { 137(33-34), 483-485. }\end{array}$ & $\begin{array}{l}636 \text { ambulatory patients with } \\
\text { acute respiratory tract } \\
\text { infections }\end{array}$ & $\begin{array}{l}\text { Assessed agreement with } 2 \\
\text { statements }\end{array}$ & $\begin{array}{l}66 \% \text { patients agreed with leaving decision } \\
\text { making to the clinicians } \\
\text { Patients who preferred shared decision making } \\
\text { were more likely to be younger, better educated } \\
\text { and in more discomfort }\end{array}$ \\
\hline $\begin{array}{l}\text { Deber, R. B., Kraetschmer, N., } \\
\text { Urowitz, S., \& Sharpe, N. (2007) } \\
\text { [17] Do people want to be } \\
\text { autonomous patients? Preferred } \\
\text { roles in treatment decision-making } \\
\text { in several patient populations. } \\
\text { Health Expectations: An } \\
\text { International Journal of Public } \\
\text { Participation in Health Care and } \\
\text { Health Policy, 10(3), 248-258. }\end{array}$ & $\begin{array}{l}2,754 \text { various health } \\
\text { conditions }\end{array}$ & $\begin{array}{l}\text { Secondary analysis of a } \\
\text { series of survey/interview } \\
\text { based studies measuring } \\
\text { preferred role } \\
\text { Used Problem-Solving } \\
\text { Decision-Making } \\
\text { (PSHARED DECISION } \\
\text { MAKING) scale with one or } \\
\text { both of the Current Health } \\
\text { condition and Chest Pain } \\
\text { vignettes }\end{array}$ & $\begin{array}{l}\text { Few preferred autonomous role ( } 1.2 \% \text { current } \\
\text { health; } 0.7 \% \text { chest pain) } \\
\text { Most preferred shared decision making }(77.8 \% \\
\text { current health; } 65.1 \% \text { chest pain) or a passive } \\
\text { role ( } 20.3 \% \text { current health; } 34.1 \% \text { chest pain) } \\
\text { Familiarity with condition increases desire for } \\
\text { shared decision making } \\
\text { Older and less education most likely to prefer } \\
\text { passive roles }\end{array}$ \\
\hline $\begin{array}{l}\text { Elkin, E. B., Kim, S. H., Casper, E. } \\
\text { S., Kissane, D. W., \& Schrad D. } \\
\text { (2007) [18] Desire for information } \\
\text { and involvement in treatment } \\
\text { decisions: elderly cancer patients' } \\
\text { preferences and their physicians' } \\
\text { perceptions. Journal of Clinical } \\
\text { Oncology: Official Journal of the } \\
\text { American Society of Clinical } \\
\text { Oncology, 25(33), 5275-5280. }\end{array}$ & $\begin{array}{l}73 \text { metastatic colorectal } \\
\text { cancer patients age } 70-89 \text { yrs } \\
19 \text { treating oncologists }\end{array}$ & $\begin{array}{l}\text { Assessed patient preferences } \\
\text { for prognostic info and for } \\
\text { involvement in treatment } \\
\text { DM } \\
\text { Asked oncologists to } \\
\text { describe perceptions of } \\
\text { patient preferences }\end{array}$ & $\begin{array}{l}44 \% \text { wanted info about expected survival when } \\
\text { they made a decision } \\
\text { Preference for prognostic info was more common } \\
\text { among men than women ( } 56 \% \mathrm{v} 29 \%) \\
52 \% \text { of patients preferred a passive role in } \\
\text { treatment DM } \\
\text { Physician perceptions were in concordance for } \\
44 \% \text { of patient-physician pairs and for decision } \\
\text { control in } 41 \% \text { of pairs }\end{array}$ \\
\hline $\begin{array}{l}\text { Gilbar, R. \& Gilbar, O. (2007) [20] } \\
\text { The Medical Decision-Making } \\
\text { Process and the Family: the Case of } \\
\text { Breast Cancer Patients and their } \\
\text { Husbands. Bioethics, April } 11 .\end{array}$ & $\begin{array}{l}57 \text { breast cancer patients and } \\
\text { their husbands }\end{array}$ & $\begin{array}{l}\text { Questionnaires measuring } \\
\text { doctor-patient/spouse } \\
\text { relationships (paternalism, } \\
\text { autonomy) and decision } \\
\text { making }\end{array}$ & $\begin{array}{l}\text { Patients believe they have a key role in decision } \\
\text { making process }(93 \%) \text { and that the participation } \\
\text { of their husbands, and their agreement with the } \\
\text { decision is important ( } 84 \% \text { and } 89 \%) \\
\text { Both the patients and their husbands prefer } \\
\text { shared decision making to paternalistic or } \\
\text { autonomy-based approaches }\end{array}$ \\
\hline $\begin{array}{l}\text { Heesen, C., Kasper, J., Segal, J., } \\
\text { Kopke, S., \& Muhlhauser, I. (2004) } \\
\text { [21] Decisional role preferences, } \\
\text { risk knowledge and information } \\
\text { interests in patients with multiple } \\
\text { sclerosis. Multiple Sclerosis } \\
\text { (Houndmills, Basingstoke, } \\
\text { England), 10(6), 643-650. }\end{array}$ & $\begin{array}{l}219 \text { randomly selected MS } \\
\text { patients }\end{array}$ & $\begin{array}{l}\text { Mailed questionnaires } \\
\text { assessing knowledge of } \\
\text { risks in MS, perception of } \\
\text { own knowledge level, } \\
\text { information interests, and } \\
\text { role preferences }\end{array}$ & $\begin{array}{l}79 \% \text { of patients preferred an active role in } \\
\text { treatment decisions }\end{array}$ \\
\hline $\begin{array}{l}\text { Scheibler, F., Stoffel, M. P., Barth, } \\
\text { C., Kuck, C., Steffen, P., } \\
\text { Baldamus, C. A., et al. (2005) [22] } \\
\text { Shared decision-making as a new } \\
\text { quality indicator in nephrology: a } \\
\text { nationwide survey in Germany. } \\
\text { Medizinische Klinik (Munich, } \\
\text { Germany: 1983), 100(4), 193-199. }\end{array}$ & $\begin{array}{l}6614 \text { end-stage renal disease } \\
\text { patients }\end{array}$ & $\begin{array}{l}\text { Patients' perceived } \\
\text { involvement in care (PICS) }\end{array}$ & $\begin{array}{l}82 \% \text { of the questioned patients feel their } \\
\text { physicians' facilitated involvement in decision } \\
\text { making. } \\
81 \% \text { of the patients actively inform themselves } \\
\text { concerning their disease and treatment options. } \\
69 \% \text { state that shared decision making has taken } \\
\text { place. } \\
\text { Age, years on dialysis and gender correlate with } \\
\text { perceived involvement. }\end{array}$ \\
\hline
\end{tabular}


(Table 1) contd.....

\begin{tabular}{|c|c|c|c|}
\hline Study and Investigators & Participants & Measures & Outcomes Under Interventions \\
\hline $\begin{array}{l}\text { Spies, C. D., Schulz, C. M., Weiss- } \\
\text { Gerlach, E., Neuner, B., Neumann, } \\
\text { T., von Dossow, V., et al. (2006) } \\
\text { [23] Preferences for shared } \\
\text { decision making in chronic pain } \\
\text { patients compared with patients } \\
\text { during a premedication visit. Acta } \\
\text { Anaesthesiologica Scandinavica, } \\
\text { 50(8), 1019-1026. }\end{array}$ & $\begin{array}{l}190 \text { chronic pain patients } \\
151 \text { patients of premedication }\end{array}$ & $\begin{array}{l}\text { The autonomy preference } \\
\text { index (API, measuring } \\
\text { preference for involvement } \\
\text { and desire for information) } \\
\text { and the perceived } \\
\text { involvement in care scale } \\
\text { (PICS, measuring patients' } \\
\text { perception of easier } \\
\text { involvement by doctors and } \\
\text { information exchange) }\end{array}$ & $\begin{array}{l}\text { Patient of the premedication visit had } \\
\text { significantly higher shared decision making } \\
\text { scores. } \\
\text { Desire for information was high, but there were } \\
\text { no differences between groups. } \\
\text { Younger patients, women and patients with } \\
\text { higher educational level had more desire for } \\
\text { shared decision making. } \\
\text { PICS scores were basically influenced by groups: } \\
\text { chronic pain patients felt more facilitated by and } \\
\text { had more information exchange than patients in } \\
\text { the premedication visit. }\end{array}$ \\
\hline $\begin{array}{l}\text { Vogel, B. A., Helms, A. W., \& } \\
\text { Hasenburg, A. (2008) [24] } \\
\text { Concordance between patients' } \\
\text { desired and actual decision-making } \\
\text { roles in breast cancer care. Psycho- } \\
\text { Oncology, 17(2), 182-189. }\end{array}$ & 137 breast cancer patients & $\begin{array}{l}\text { Survey within one week of } \\
\text { surgery or chemo measuring } \\
\text { preferences and experiences } \\
\text { in Shared Decision Making } \\
\text { and patient-physician } \\
\text { concordance }\end{array}$ & $\begin{array}{l}40.2 \% \text { preferred the physician to make the } \\
\text { treatment decision. } \\
63.4 \% \text { were able to fulfill their preferred } \\
\text { decision-making role. } \\
\text { Breast cancer patients who wanted the physician } \\
\text { to make the decision and patients who wanted to } \\
\text { make the decision on their own were more likely } \\
\text { to have their preferences met than patients who } \\
\text { wished to share the decision }(\mathrm{p}<0.01) \text {. }\end{array}$ \\
\hline $\begin{array}{l}\text { Vogel, B. A., Bengel, J. \& Helmes, } \\
\text { A. W. (2008) [25] Information and } \\
\text { decision making: Patients' needs } \\
\text { and experiences in the course of } \\
\text { breast cancer treatment. Patient } \\
\text { Education \& Counseling, 71(1):79- } \\
85 .\end{array}$ & $\begin{array}{l}135 \text { German breast cancer } \\
\text { patients }\end{array}$ & $\begin{array}{l}\text { Survey within a week of } \\
\text { either surgery or the } \\
\text { beginning of neo-adjuvant } \\
\text { chemotherapy measuring } \\
\text { specific information needs }\end{array}$ & $\begin{array}{l}\text { Significant decrease in the importance of specific } \\
\text { information needs. The quality of received } \\
\text { information through the physician was rated } \\
\text { significantly better at baseline than } 6 \text { months } \\
\text { later. Nearly half of all patients changed their } \\
\text { decision making preference at least at one } \\
\text { assessment point. Shared decision making rarely } \\
\text { took place in the first } 6 \text { months of treatment. }\end{array}$ \\
\hline $\begin{array}{l}\text { Bieber, C., Muller, K. G., } \\
\text { Blumenstiel, K., Hochlehnert, A., } \\
\text { Wilke, S., Hartmann, M., et al. } \\
\text { (2008) [7] A shared decision- } \\
\text { making communication training } \\
\text { program for physicians treating } \\
\text { fibromyalgia patients: Effects of a } \\
\text { randomized controlled trial. Journal } \\
\text { of Psychosomatic Research, 64(1), } \\
\text { 13-20. }\end{array}$ & $\begin{array}{l}44 \text { experimental (Shared } \\
\text { Decision Making) } \\
41 \text { control (Info only) } \\
\text { Mean age } 49.9 \text { yrs } \\
91.8 \% \text { female }\end{array}$ & $\begin{array}{l}\text { Patient questionnaires on } \\
\text { physician-patient interaction } \\
\text { and decisional processes } \\
\text { Physician questionnaire on } \\
\text { interaction difficulties } \\
\text { Measured immediately after } \\
\text { intervention }\end{array}$ & $\begin{array}{l}\text { Quality of physician-patient interaction was sig. } \\
\text { higher in the shared decision making group than } \\
\text { in the info-only group }(\mathrm{P}<.001) \\
\text { RCT } \\
\text { Shared decision making group physicians trained } \\
\text { in shared decision making and had access to a } \\
\text { computer-based info package } \\
\text { Info group had info package only }\end{array}$ \\
\hline $\begin{array}{l}\text { Bieber, C., Muller, K. G., } \\
\text { Blumenstiel, K., Schneider, A., } \\
\text { Richter, A., Wilke, S., et al. (2006) } \\
\text { [32] Long-term effects of a shared } \\
\text { decision-making intervention on } \\
\text { physician-patient interaction and } \\
\text { outcome in fibromyalgia. A } \\
\text { qualitative and quantitative } 1 \text { year } \\
\text { follow-up of a RCT. Patient } \\
\text { Education \& Counseling, 63(3), } \\
\text { 357-366. }\end{array}$ & $\begin{array}{l}67 \text { fibromyalgia patients in } \\
\text { either shared decision making } \\
\text { or info group } \\
44 \text { fibromyalgia patients } \\
\text { receiving usual treatment as } \\
\text { comparison group }\end{array}$ & $\begin{array}{l}\text { Combined qual. \& quan. } \\
\text { Approach } \\
\text { Follow-up after } 3 \text { months } \\
\text { and } 1 \text { year }\end{array}$ & $\begin{array}{l}\text { Best quality of physician-patient interaction in } \\
\text { shared decision making group, then info group } \\
\text { Improved coping in shared decision making } \\
\text { group } \\
\text { Directly health related outcome variables had not } \\
\text { improved in any of the groups at } 1 \text { year } \\
\text { Shared decision making group physicians trained } \\
\text { in shared decision making and had access to a } \\
\text { computer-based info package } \\
\text { Info group had info package only } \\
\text { Comparison group had no intervention }\end{array}$ \\
\hline $\begin{array}{l}\text { Boivin, A., Legare, F. \& Gagnon, } \\
\text { M. P. (2008) [26] Competing } \\
\text { norms: Canadian rural family } \\
\text { physicians' perceptions of clinical } \\
\text { practice guidelines and shared } \\
\text { decision-making. Journal of Health } \\
\text { Services Research \& Policy, 13(2), } \\
\text { 79-84. }\end{array}$ & $\begin{array}{l}17 \text { family physicians and } \\
\text { residents in Canadian rural } \\
\text { town }\end{array}$ & $\begin{array}{l}\text { Qualitative study using a } \\
\text { semi-structured focus group } \\
\text { interview }\end{array}$ & $\begin{array}{l}\text { Guidelines were seen as helping clinicians to } \\
\text { make decisions on behalf of their patient } \\
\text { For interventions with uncertain benefit or that } \\
\text { carried significant trade-off for patients, } \\
\text { guidelines were seen as a tool that should inform } \\
\text { shared decision making } \\
\text { Pressure to apply guideline recommendations } \\
\text { perceived as potential barrier to patient } \\
\text { participation in shared decision making }\end{array}$ \\
\hline
\end{tabular}


(Table 1) contd....

\begin{tabular}{|c|c|c|c|}
\hline Study and Investigators & Participants & Measures & Outcomes Under Interventions \\
\hline $\begin{array}{l}\text { Elkin, E. B., Kim, S. H., Casper, E. } \\
\text { S., Kissane, D. W., \& Schrag, D. } \\
\text { (2007) [18] Desire for information } \\
\text { and involvement in treatment } \\
\text { decisions: elderly cancer patients' } \\
\text { preferences and their physicians' } \\
\text { perceptions. Journal of Clinical } \\
\text { Oncology: Official Journal of the } \\
\text { American Society of Clinical } \\
\text { Oncology, 25(33), 5275-5280. }\end{array}$ & $\begin{array}{l}73 \text { metastatic colorectal } \\
\text { cancer patients age } 70-89 \text { yrs } \\
19 \text { treating oncologists }\end{array}$ & $\begin{array}{l}\text { Assessed patient preferences } \\
\text { for prognostic info and for } \\
\text { involvement in treatment } \\
\text { DM } \\
\text { Asked oncologists to } \\
\text { describe perceptions of } \\
\text { patient preferences }\end{array}$ & $\begin{array}{l}44 \% \text { wanted info about expected survival when } \\
\text { they made a decision } \\
\text { Preference for prognostic info was more common } \\
\text { among men than women ( } 56 \% \mathrm{v} 29 \%) \\
52 \% \text { of patients preferred a passive role in } \\
\text { treatment DM } \\
\text { Physician perceptions were in concordance for } \\
44 \% \text { of patient-physician pairs and for decision } \\
\text { control in } 41 \% \text { of pairs }\end{array}$ \\
\hline $\begin{array}{l}\text { Heisler, M., Vijan, S., Anderson, R. } \\
\text { M., Ubel, P. A., Bernstein, S. J., \& } \\
\text { Hofer, T. P. (2003) [27] When do } \\
\text { patients and their physicians agree } \\
\text { on diabetes treatment goals and } \\
\text { strategies, and what difference does } \\
\text { it make? Journal of General } \\
\text { Internal Medicine: Official Journal } \\
\text { of the Society for Research and } \\
\text { Education in Primary Care Internal } \\
\text { Medicine, 18(11), 893-902. }\end{array}$ & 127 patient-physician pairs & $\begin{array}{l}\text { Surveyed about top } 3 \\
\text { diabetes treatment goals and } \\
\text { strategies }\end{array}$ & $\begin{array}{l}\text { Agreement of top treatment goals and strategies } \\
\text { was low } \\
\text { Physician reports of having discussed more } \\
\text { content areas of diabetes self-care were } \\
\text { associated with greater agreement on treatment } \\
\text { strategies, which in turn was associated with } \\
\text { higher patient diabetes self-care efficacy and } \\
\text { assessments of their diabetes self-management }\end{array}$ \\
\hline $\begin{array}{l}\text { Schneider, H. B., \& Sandholzer, H. } \\
\text { (2008) [29] } \\
\text { Shared decision making: evaluation } \\
\text { of German medical students' } \\
\text { preferences. Journal of Evaluation } \\
\text { in Clinical Practice, 14(3):435-438. }\end{array}$ & 188 medical students & $\begin{array}{l}\text { Student perceptions of } \\
\text { patient centeredness and the } \\
\text { priorities of students for a } \\
\text { change in medical care }\end{array}$ & $\begin{array}{l}\text { Receiving more information and undergoing the } \\
\text { process of shared decision making was the most } \\
\text { important choice; selected by } 43.2 \% \text { as their first } \\
\text { priority. } \\
\text { The second choice was found to be consultation } \\
\text { time ( } 16.2 \%) \text { which also refers to the patient- } \\
\text { doctor relationship. } \\
\text { Shorter queues for tests, also considered } \\
\text { important for more patient autonomy, were } \\
\text { ranked third (14.6\%). } \\
\text { Medical students participating in this study were } \\
\text { least interested in access to specialists, cost of } \\
\text { medications and continuity of care. }\end{array}$ \\
\hline $\begin{array}{l}\text { Shepherd, H. L., Tattersall, M. H., } \\
\& \text { Butow, P. N. (2007) [28] The } \\
\text { context influences doctors' support } \\
\text { of shared decision-making in } \\
\text { cancer care. British Journal of } \\
\text { Cancer, 97(1), 6-13. }\end{array}$ & 624 cancer clinicians & $\begin{array}{l}\text { Surveyed to identify their } \\
\text { usual approach to decision- } \\
\text { making and their comfort } \\
\text { with different decision- } \\
\text { making styles when } \\
\text { discussing treatment with } \\
\text { patients. }\end{array}$ & $\begin{array}{l}\text { Most cancer doctors }(62.4 \%) \text { reported using } \\
\text { shared decision making and being most } \\
\text { comfortable with this approach. } \\
\text { Differences were apparent between reported high } \\
\text { comfort with shared decision making and less } \\
\text { frequent usual practice. } \\
\text { Multivariate analysis showed that specialisation } \\
\text { in breast or urological cancers compared to other } \\
\text { cancers, high caseload of new patients per month } \\
\text { and female gender were each independently } \\
\text { associated with increased likelihood of use of } \\
\text { shared decision making. }\end{array}$ \\
\hline
\end{tabular}

Family relationships as they relate to shared decision making have been examined. Gilbar \& Gilbar [19] studied 57 spouse pairs where the woman had breast cancer. They found views generally concordant between spouses. In the great majority of the pairs (about 90\%) both believed the patient had a key role in clinical decision making and that the participation of the spouse was important. Heesen et al. [20] studied 219 outpatients with multiple sclerosis. Over seventy-five percent indicated a preference for an active role in treatment decisions. Neither measured nor perceived knowledge regarding the condition were significant in the preference for a role in making decisions. In one of the largest surveys on the topic, Scheibler et al. [21] studied 6,614 patients with end stage renal disease. The great majority $(81 \%)$ believed that the clinician had tried to facilitate the patient's involvement in decision making and most of these patients $(69 \%)$ believed that joint decision making had, in fact, occurred. The perception of having been involved correlated with age, years on dialysis, and gender. Spies et al. [22] studied 341 patients and compared the 190 having received treatment for chronic pain with the 151 who were yet to receive treatment. They used the Autonomy Preference Index (API) to assess preferences for involvement in decision making. They found no differences between the 
groups. Younger patients, women and those with more education preferred shared decision making.

Vogel et al. [23] studied 137 women with breast cancer. They found that most $(40 \%)$ preferred the clinician to make decisions regarding treatment. Patients who preferred shared decision making were less likely to have their preference met by their clinicians. The range of options available to the woman and the level of her depression influenced her decision making preference. The same investigators Vogel et al. [24] studied 135 breast cancer patients at baseline before surgery and at three and six months subsequently. At the six months time point patients reported improvements in the quality of information provided to them by their clinicians. Nearly half of all patients changed their decision making preference at least once during the study period. Shared decision making rarely took place in the first six months of treatment.

\section{The Views of Clinicians Regarding Shared Decision Making and Concordance with the Views of their Patients}

As noted, patients and their clinicians are not necessarily in accord regarding shared decision making. Fewer studies have examined the health care provider's perspective than the patient's view. Table $\mathbf{1}$ outlines these beliefs as expressed in recent studies.

In a small qualitative study, Boivin et al. [25] explored the views of rural family physicians and their patients $(\mathrm{N}=17)$. They conducted a qualitative study with 17 patients. In situations where the treatment decision was less clear, physicians found that clinical guidelines enhanced joint decision making. However, physicians perceived a tension in some cases between adhering to clinical guidelines and respecting the patient's treatment preferences. Elkin et al. [17] found that only $44 \%$ of the 73 patient-clinician pairs they studied were in accord regarding patient preferences for information about their condition and $41 \%$ in accord regarding shared decision making preferences.

Heisler et al. [26] studied 127 patients with diabetes and their primary care providers. They found that concordance between provider and patient was low (all kappa's less than 0.40). Patients having higher levels of schooling, greater confidence in their diabetes treatment regimen, and who had actively shared in decision making with their clinicians were more likely to agree with their provider regarding treatment goals and strategies. Further, the more the clinician had discussed the treatment strategies with the patient, the greater their agreement on treatment goals. Shepherd et al. [27] studied 624 cancer specialist clinicians to assess their decision making approach and comfort with various styles. They found nearly two thirds $(62 \%)$ reported using shared decision making and being most comfortable with this approach. Analyses showed that specialization in certain cancer areas (breast and urological), being a female clinician, and having a higher monthly caseload of new patients were each independently associated with more use of shared decision making by the clinicians. Schneider \& Sandholzer [28] studied 188 medical students regarding their views on the most important elements of the physician-patient relationship. Just under half (43\%) described shared decision making as their top priority.

\section{Health Outcomes and Shared Decision Making}

A critical question is whether or not shared decision making is associated with better patient outcomes. Joosten et al. [29] reported on a systematic review of outcomes associated with shared decision making in randomized clinical trials conducted from 1985 to 2006. Most studies were completed between 2000 and 2004. They found that five showed no health outcome differences between the shared decision making group and controls, five showed positive results, and one showed no short term results but positive longer term effects. More recent studies have added to the picture of health outcomes associated with shared decision making and these are presented in Table 2.

Naik et al. [30] studied 566 older diabetic adults regarding their hypertension control. They found two communication factors to be associated with hypertension control. The most significant of these was a patient's preference for clinicians employing shared decision making.

In a second study, Bieber et al. [31] followed at baseline, three months, and one year, 67 adult, ambulatory fibromyalgia patients who participated in either a shared decision making group (which clinicians were especially trained to deliver) or a conventional information-only group. Forty-four fibromyalgia patients were recruited from the same practices to serve as a comparison group. Findings indicated that the quality of the clinician-patient interaction was highest in the shared decision making group followed by the information only group. No health care outcomes were identified in any of the three groups at the one year follow up time point.

The Bieber et al. [31] study randomized 85 adult patients with fibromyalgia into a shared decision making group or a conventional information-only group. They again found the quality of clinician-patient interaction was significantly higher in the shared decision making group but no differences were noted subsequently in patient outcomes. Corser et al. [32] studied shared decision making in a convenience sample of 58 individuals with type 2 diabetes. The majority of nurses and doctors who were trained to engage in shared decision making with these patients reported that using the approach did not impose major demands upon them. The patients of these clinicians subsequently had at least one diabetes management goal documented in the medical record (75\%). HbA1c level, and weight both showed a trend toward improvement following the intervention but results were not statistically significant.

Edwards et al. [33] studied 747 patients with known atrial fibrillation, prostatism, menorrhagia or menopausal symptoms. Patients were invited to see clinicians a) who had been trained in shared decision making or b) who were not so trained but used conventional risk communication techniques. Follow up at one month found no statistically significant health outcomes according to group. The same investigators Ewlyn et al. [34] assessed whether or not the training designed to impart shared decision making skills to clinicians had enabled them to engage in the approach and whether or not the patients' view of the consultation changed subsequent to the training. They found that the clinicians' perception of agreement with the patient regarding treatment goals increased following training. They also found that the 
Table 2. Recent Intervention Studies of Shared Decision Making

\begin{tabular}{|c|c|c|c|}
\hline $\begin{array}{l}\text { Corser, W., Holmes-Rovner, M., Lein, } \\
\text { C., \& Gossain, V. (2007) [33] A } \\
\text { shared decision-making primary care } \\
\text { intervention for type } 2 \text { diabetes. The } \\
\text { Diabetes Educator, 33(4), 700-708. }\end{array}$ & $\begin{array}{l}58 \text { Type } 2 \\
\text { diabetes } \\
\text { patients }\end{array}$ & $\begin{array}{l}\text { HbA1C } \\
\text { Weight } \\
\text { BP } \\
\text { Pre- \& post-intervention } \\
\text { questionnaires } \\
\text { Documented diabetes goals }\end{array}$ & $\begin{array}{l}\text { Brief shared decision making goal-setting intervention } \\
75.9 \% \text { of patients had at least one diabetes goal } \\
\text { documented after intervention } \\
\text { HbA1C, weight, and diabetes empowerment score } \\
\text { showed a trend toward improvement } \\
\text { Perceived knowledge of diabetes and treatments } \\
\text { increased significantly as did the mean \# of documented } \\
\text { diabetes mgmt goals }\end{array}$ \\
\hline $\begin{array}{l}\text { Loh, A., Simon, D., Wills, C. E., } \\
\text { Kriston, L., Niebling, W., \& Harter, } \\
\text { M. (2007) [36] The effects of a shared } \\
\text { decision-making intervention in } \\
\text { primary care of depression: a cluster- } \\
\text { randomized controlled trial. Patient } \\
\text { Education and Counseling, 67(3), 324- } \\
\text { 332. }\end{array}$ & $\begin{array}{l}23 \text { PCP } \\
405 \text { patients } \\
\text { with newly } \\
\text { diagnosed } \\
\text { depression }\end{array}$ & $\begin{array}{l}\text { Patient perceived involvement in } \\
\text { care scale (PICS) and a patient } \\
\text { participation scale (MSH-scale). } \\
\text { Patient satisfaction was measured } \\
\text { by the CSQ- } 8 \text { questionnaire. } \\
\text { Treatment adherence was } \\
\text { evaluated by patient and provider } \\
\text { self-report. } \\
\text { Depression severity and } \\
\text { remission outcomes were } \\
\text { assessed with the Brief PHQ-D. }\end{array}$ & $\begin{array}{l}\text { Cluster-randomized controlled intervention } \\
\text { Physician training and patient-centered decision aid } \\
\text { compared to usual care in primary care settings } \\
\text { Physician facilitation of patient participation improved } \\
\text { significantly and to a greater extent in the intervention } \\
\text { compared to the control group. } \\
\text { There was no intervention effect for depression severity } \\
\text { reduction. } \\
\text { Doctor facilitation of patient participation, patient-rated } \\
\text { involvement, and physician assessment of adherence } \\
\text { improved only in the intervention group. } \\
\text { Patient satisfaction at post-intervention was higher in } \\
\text { the intervention group compared to the control group. } \\
\text { The consultation time did not differ between groups. }\end{array}$ \\
\hline $\begin{array}{l}\text { Muller, K. G., Richter, A., Bieber, C., } \\
\text { Blumenstiel, K., Wilke, S., } \\
\text { Hochlehnert, A., et al. (2004) [37] The } \\
\text { process of shared decision making in } \\
\text { chronic pain patients. Evaluation and } \\
\text { modification of treatment decisions. } \\
\text { Zeitschrift Fur Arztliche Fortbildung } \\
\text { Und Qualitatssicherung: In } \\
\text { Zusammenarbeit Mit Der Kaiserin- } \\
\text { Friedrich-Stiftung Fur Das Arztliche } \\
\text { Fortbildungswesen, 98(2), 95-100. }\end{array}$ & 39 physicians & $\begin{array}{l}\text { Physicians who had undergone } \\
\text { special communication training } \\
\text { were examined as to whether } \\
\text { these physicians actually } \\
\text { exercised the option of revising } \\
\text { their treatment decisions }\end{array}$ & $\begin{array}{l}\text { In } 87.2 \% \text { of the consultations the therapy decisions were } \\
\text { modified within three months after the first encounter. } \\
\text { Patients considered to be "difficult" were less likely to } \\
\text { modify their decisions. }\end{array}$ \\
\hline $\begin{array}{l}\text { Wensing, M., Elwyn, G., Edwards, A., } \\
\text { Vingerhoets, E., \& Grol, R. (2002) } \\
\text { [44] Deconstructing patient centered } \\
\text { communication and uncovering shared } \\
\text { decision making: an observational } \\
\text { study. BMC Medical Informatics and } \\
\text { Decision Making, 2, } 2 \text {. }\end{array}$ & $\begin{array}{l}60 \text { GPs } \\
596 \text { adult } \\
\text { patients }\end{array}$ & $\begin{array}{l}\text { Scales for patient centered } \\
\text { communication and shared } \\
\text { decision making } \\
\text { Recorded consultation sessions }\end{array}$ & $\begin{array}{l}\text { The scales for PCC and shared decision making were } \\
\text { weakly associated } \\
\text { Physicians varied more on shared decision making than } \\
\text { on PCC. The intracluster correlation of the PCC and } \\
\text { shared decision making scales were, respectively, } 0.34 \\
\text { and } 0.19 \text {. } \\
\text { Hypotheses regarding associations with patient } \\
\text { characteristics were not confirmed. } \\
\text { Neither PCC nor shared decision making scores were } \\
\text { related to patient gender, education, age, functional } \\
\text { health status or existence of chronic conditions. }\end{array}$ \\
\hline
\end{tabular}


(Table 2) contd.....

\begin{tabular}{|c|c|c|c|}
\hline Study and Investigators & Participants & Measures & Outcomes Under Interventions \\
\hline $\begin{array}{l}\text { Edwards, A., Elwyn, G., Hood, K., } \\
\text { Atwell, C., Robling, M, Houston, H., } \\
\text { Kinnersley, P., Russell, I., \& Shared } \\
\text { Decision Making Study Group (2004) } \\
\text { [34] Patient-based outcome results } \\
\text { from a cluster randomized trial of } \\
\text { shared decision making skill } \\
\text { development and use of risk } \\
\text { communication aids in general } \\
\text { practice. Family Practice, 21(4), 347- } \\
\text { 354. }\end{array}$ & $\begin{array}{l}20 \text { recently } \\
\text { qualified GPs } \\
\text { in rural and } \\
\text { urban general } \\
\text { practices in } \\
\text { South Wales. } \\
747 \text { patients } \\
\text { with known } \\
\text { atrial } \\
\text { fibrillation, } \\
\text { prostatism, } \\
\text { menorrhagia or } \\
\text { menstrual } \\
\text { symptoms. }\end{array}$ & $\begin{array}{l}\text { GPs randomized to receive } \\
\text { training in (i) shared decision } \\
\text { making skills; or (ii) use of } \\
\text { simple risk communication aids. } \\
\text { Alternative training was then } \\
\text { provided for final study phase. } \\
\text { Patients randomly allocated to } \\
\text { consultation during baseline or } \\
\text { intervention } 1 \text { (shared decision } \\
\text { making or risk communication } \\
\text { aids) or intervention } 2 \text { phases. A } \\
\text { randomly selected half of the } \\
\text { consultations took place at } \\
\text { 'research clinics' to evaluate the } \\
\text { effects of more time for } \\
\text { consultations, compared to usual } \\
\text { surgery time. }\end{array}$ & $\begin{array}{l}\text { No statistically significant changes in patient-based } \\
\text { outcomes due to the training interventions were found. } \\
\text { Patients' confidence in the decision ( } 2.1 \text { increase, } 95 \% \\
\text { CI } 0.7-3.5, \mathrm{P}<0.01) \text { and expectation to adhere to } \\
\text { chosen treatments }(0.07 \text { increase, } 95 \% \text { CI } 0.04-1.36, \mathrm{P}< \\
0.05) \text { were significantly greater among patients seen in } \\
\text { the research clinics. } \\
\text { Most outcomes deteriorated between exit and } 1 \text { month } \\
\text { later. There was no interaction between intervention } \\
\text { effects. }\end{array}$ \\
\hline $\begin{array}{l}\text { Ewlyn, G., Edwards, A., Hood, K., } \\
\text { Robling, M., Atwell, C., Russell, I., } \\
\text { Wensing, M., \& Grol, R. (2004) [35] } \\
\text { Achieving involvement: process } \\
\text { outcomes from a cluster randomized } \\
\text { trial of shared decision making skill } \\
\text { development and use of risk } \\
\text { communication aids in general } \\
\text { practice. Family Practice, 21(4)337- } \\
346 .\end{array}$ & $\begin{array}{l}20 \text { recently } \\
\text { qualified GPs } \\
\text { in rural and } \\
\text { urban general } \\
\text { practices in } \\
\text { South Wales. } \\
747 \text { patients } \\
\text { with known } \\
\text { atrial } \\
\text { fibrillation, } \\
\text { prostatism, } \\
\text { menorrhagia or } \\
\text { menstrual } \\
\text { symptoms. }\end{array}$ & $\begin{array}{l}\text { Patients allocated randomly to a } \\
\text { consultation during baseline or } \\
\text { intervention } 1 \text { (Shared decision } \\
\text { making or risk communication } \\
\text { aids) or intervention } 2 \text { phases. } \\
\text { Half the consultations were } \\
\text { randomly selected for audio- } \\
\text { taping, of which } 352 \text { patients } \\
\text { attended. } \\
\text { After baseline, GPs were } \\
\text { randomized to receive training in } \\
\text { (i) shared decision making skills } \\
\text { or (ii) the use of simple risk } \\
\text { communication aids. Alternative } \\
\text { training was then provided for } \\
\text { final study phase. } \\
\text { Rates assessed audio tapes to } \\
\text { determine levels of patient } \\
\text { involvement. } \\
\text { Clinicians completed } \\
\text { questionnaires after each } \\
\text { consultation assessing perceived } \\
\text { clinician-patient agreement and } \\
\text { level of patient involvement in } \\
\text { decisions. }\end{array}$ & $\begin{array}{l}\text { Following each of the interventions, clinicians } \\
\text { significantly increased their involvement of patients in } \\
\text { decision making (OPTION score increased by } 10.6 \\
\text { following risk communication training [ } 95 \% \text { confidence } \\
\text { interval }(\mathrm{CI}) 7.9-13.3 ; \mathrm{P}, 0.001 \text { ] and by } 12.9 \text { after } \\
\text { shared decision making skill development ( } 95 \% \text { CI } 10 \text { - } \\
15.8, \mathrm{P}, 0.001) \text {, a moderate effect size. } \\
\text { Level of involvement achieved by the risk } \\
\text { communication aids was significantly increased by the } \\
\text { subsequent introduction of the skill development } \\
\text { workshop ( } 7.7 \text { increase in OPTION score, } 95 \% \text { CI } 3.4- \\
12 ; \mathrm{P}<0.001) \text {. The alternate sequence (skills followed } \\
\text { by risk communication aids) did not achieve this effect. } \\
\text { Clinicians using the risk communication tools perceived } \\
\text { significantly higher patient and clinician agreement on } \\
\text { treatment (P, } 0.001) \text {, patient satisfaction with } \\
\text { information (P, } 0.01) \text {, clinician satisfaction with } \\
\text { decision (P, } 0.01) \text { and general overall satisfaction with } \\
\text { the consultation (P, } 0.001) \text { than those who were exposed } \\
\text { to shared decision making skill development } \\
\text { workshops. }\end{array}$ \\
\hline
\end{tabular}

clinicians' views that patients were satisfied with the consultation increased. No changes in health status outcomes were reported.

Loh et al. [35] studied 23 primary care practitioners seeing 405 patients with newly diagnosed depression assigned to a) clinicians trained to engage them in shared decision making or b) clinicians providing usual care. They found patient satisfaction post intervention was higher in the shared decision making group but there were no significant health outcomes noted. Muller et al. [36] conducted a qualitative study of 39 clinicians seeing patients with fibromyalgia trained in patient shared decision making engagement and communication. They found in case records that $87 \%$ of the clinicians modified their therapy decisions subsequent to training and that changes in such determinations required more than one subsequent consultation with the patient.

\section{Discussion: What do these Studies Tell us about Shared Decision Making?}

Considered together, recent studies do not comprise a definitive picture of shared decision making. Nonetheless, some themes and patterns begin to emerge in the findings.

Shared decision making appears to be age related and is, perhaps, a generational phenomenon. Younger patients seem much more likely to view shared decision making as a preferred style of patient-provider interaction. This difference in view may be a result of a new generation of patients exposed over the recent past to more participatory forms of interactions with clinicians and having higher communication expectations. On the other hand, it may be that as people age they are more at ease with leaving decisions to their health care providers [37]. These patients may also have lower capacity or levels of health literacy and choose to be less involved. In any case, being older appears to be a predictor of less enthusiasm for shared decision 
making. Higher levels of education increase the likelihood that a patient will prefer shared decision making. More education may enhance confidence (also shown to be associated with shared decision making preference), and/or the tendency to seek more information about one's health condition, as well as, the expectation of more personal control in the encounter with clinicians. Social distance between providers and their patients has been shown to reduce questioning by patients and increase acceptance of nurses' and other clinicians views of care needs in the given situation Rutland [38]. Education can reduce social distance and this may contribute to the creation of a different set of patient expectations and preferences.

Limited but interesting data suggest that patient preferences for shared decision making may be associated with the seriousness of the health condition, which preference for it may change over time, and it may be more likely to be preferred after the acute stage of a problem. All these factors are deserving of further exploration.

Recent work illustrates a diversion in the views of patients and providers regarding shared decision making. Patients (excluding elderly ones) are somewhat more in favor of shared decision making while clinicians are relatively less enthusiastic and less likely to adopt it as a consultation strategy. There may be differences in provider enthusiasm according to clinical specialty. Nonetheless, large numbers of patients and health professionals appear to support shared decision making as a strategy in high quality health care.

Some scant evidence suggests that patient perception of the quality of the consultation and the satisfaction with care rendered is enhanced by shared decision making. However, the extent to which shared decision making is associated with improved patient health outcomes remains a question.

No doubt the differing and imprecise definitions of shared decision making and the lack of evidence for, indeed, agreement about its principle components influence the contribution of existing work to understanding the concept. Despite the sometimes vague application of the idea, recent research reflects at least two fundamental premises for shared decision making. First is the idea that shared decision making leads to better health outcomes. Presumably, this is because patients offer more useful information enabling providers to identify more and more robust clinical options; that patients are more motivated to follow recommendations that they themselves have helped to formulate; and that the resulting jointly chosen clinical regimen simply holds greater potential for efficacy as it is more in line with the patients' lifestyle and perceived capabilities. Whether or not improved health status is the prevailing result of shared decision making, however, requires more evidence.

Second is the idea that patient satisfaction with care is a guiding principle of professional practice. As patients' interest increases regarding more control over their health and health care, and as ideas supporting more democratic processes take hold within the health system, shared decision making is more associated with patient satisfaction. Patient satisfaction has been shown to be a factor in sustaining relationships between professional and patient [39]. It is also one of the professional if not personal rewards of being a health care provider. Further, the concept appears to be increasingly important in newer modes of integrated health care and a factor in the definition of success of delivery organizations. With regards to patient outcomes, acceptable patient satisfaction with care as a consistently associated result of shared decision making will require further exploration.

This review indicates that regardless of the preferred premise for shared decision making, more evidence of resulting health outcomes is needed to rationalize its widespread use as part of patient care. The particular role of nurses in shared decision making is very important to explore. Nurses are generally viewed by patients as the clinicians most likely to educate them [40] and in whom they place great trust [41]. Shared decision making, of course, relates to the provision of pharmacological therapies but also is very likely to influence patient confidence in and willingness to engage in other dimensions of effective disease self management. Nurses play central roles as providers of therapies, educators, and counselors in varied clinical settings and are critical members of multidisciplinary care teams. As such nurses are well positioned to engage patients in shared decision making and assist them to make clinical choices [42]. Shared decision making models especially designed for them in their several clinical roles need to be developed [2]. Another important consideration in shared decision making is the emphasis to be placed on children and adolescents as decision makers [43]. Available studies almost all concern the perspectives and preferences of adults and clinicians' views of patient involvement. How is decision making shared with younger patients? When does the parent cease to be the decider and the child begin? What are the patterns of three-way shared decision making? What are means by which nurses can best achieve participation by children?

\section{CONCLUSION}

As the task of clinical work increasingly shift to nurses particularly in the ongoing care and management of long term conditions, they need adequate training in the processes of interacting with patients they are likely to work with over time. Nursing theoretical frameworks have always emphasized the importance of patients' perspectives, values and preferences in establishing nurse-patient relationships. Rutland [1] has noted that implementing shared decision making in nursing care is still a novel area and requires more research. If shared decision making is to live up to the current expectations of many patients and health care providers, it must be more carefully tested. Evaluations need to reflect the work of the clinical nurse who provides the majority of care and education especially to those with chronic conditions.

\section{ACKNOWLEDGEMENT}

Thanks to Danielle Robling and Wajeeha Shuttari for their assistance with this manuscript.

\section{REFERENCES}

[1] Rutland CM. Shared decision making and nursing informatics research in Norway. Appl Nurs Res 2005; 18(2): 70-2.

[2] Stacey D, Murray MA, Legare F, Sandy D, Menard P \& O'Connor A. Decision coaching to support shared decision making: a framework, evidence, and implications for nursing practice, 
education, and policy. Worldviews Evid Based Nurs 2008; 5(1): 25-35.

[3] Golanowski M, Beaudry D, Kurz L, Laffey WJ, Hook ML. Interdisciplinary shared decision making: taking shared governance to the next level. Nurs Adm Q 2007; 31(4): 341-53.

[4] Thistlethwaite J, Evans R, Tie RN, Heal C. Shared decision making and decision aids - a literature review. Aust Fam Physician 2006; 35(7): 537-40.

[5] Butz AM, Walker JM, Pulsifer M, Winkelstein M. Shared decision making in school age children with asthma. Paediatr Nurs 2007; 33(2): $111-6$

[6] Whitney SM, Holmes-Rovner M, Grody H, Schneider C, McCullough LB, Volk RJ. Beyond shared decision making: an expanded typology of medical decisions. Med Decis Making 2008; 28(5): 699-705.

[7] Makoul G, Clayman ML. An integrative model of shared decision making in medical encounters. Patient Educ Couns 2006; 60(3): 301-12.

[8] Moumjid N, Gafni A, Bremond A, Carrere MO. Shared decision making in the medical encounter: are we all talking about the same thing? Med Decis Making 2007; 27(5): 539-46.

[9] Dy SM. Instruments for evaluating shared medical decision making: a structured literature review. Med Care Res Rev 2007; 64(6): 623-49

[10] Fraenkel L, McGraw S. What are the essential elements to enable patient participation in medical decision making? J Gen Intern Med 2007; 22(5): 614-9.

[11] Zoffmann V, Harder I, Kirkevold M. A person-centered communication and reflection model: sharing decision-making in chronic care. Qual Health Res 2008; 18(5): 670-85.

[12] Frantsve LM, Kerns RD. Patient-provider interactions in the management of chronic pain: current findings within the context of shared medical decision making. Pain Med 2007; 8(1): 25-35.

[13] Briel M, Young J, Tschudi P, Hugenschmidt C, Bucher HC, Langewitz W. Shared-decision making in general practice: do patients with respiratory tract infections actually want it? Swiss Med Wkly 2007; 137(33-34): 483- 5

[14] Caress AL, Beaver K, Luker K, Campbell M, Woodcock A. Involvement in treatment decisions: what do adults with asthma want and what do they get? Results of a cross- sectional survey. Thorax 2005; 60(3): 199-205.

[15] Kavanaugh K, Savage T, Kilpatrick S, Kimura R, Hershberger P. Life support decisions for extremely premature infants: report of a pilot study. J Pediatr Nur 2005; 20(5): 47-59.

[16] Deber RB, Kraetschmer N, Urowitz S, Sharpe N. Do people want to be autonomous patients? Preferred roles in treatment decision making in several patient populations. Health Expect 2007; 10(3): 248-58.

[17] Elkin EB, Kim SH, Casper ES, Kissane DW, Schrag D. Desire for information and involvement in treatment decisions: elderly cancer patients' preferences and their physicians' perceptions. J Clin Oncol 2007; 25(33): 5275-80.

[18] Funk LM. Who wants to be involved? Decision making preferences among residents of long-term care facilities. Can J Aging 2004; 23(1): 47-58.

[19] Gilbar R, Gilbar O. The medical decision-making process and the family: the case of breast cancer patients and their husbands. Bioethics 2009; 23(3): 183-92.

[20] Heesen C, Kasper J, Segal J, Kopke S, Muhlhauser I. Decisional role preferences, risk knowledge and information interests in patients with multiple sclerosis. Mult Scler 2004; 10(6): 643-50.

[21] Scheibler F, Stoffel MP, Barth C, Kuch C, Steffen P, Baldamus $\mathrm{CA}$. Shared decision making as a new quality indicator in nephrology: a nationwide survey in Germany. [Partizipative Entscheidungsfindung als neuer Qualitatsindikator in der Nephrologie Eine bundesweite empirische Untersuchung] Medizinische Klinik 2005; 100(4): 193-9.

[22] Spies CD, Schulz CM, Weiss-Gerlach E, Neuner B, Neumann T, von Dossow V. Preferences for shared decision making in chronic pain patients compared with patients during a premedication visit. Acta Anaesthesiologica Scandinavica 2006; 50(8): 1019-26.
[23] Vogel BA, Helmes AW, Hasenburg A. Concordance between patients' desired and actual decision-making roles in breast cancer care. Psychooncology 2008a; 17(2): 182-9.

[24] Vogel BA, Bengel J, Helmes AW. Information and decision making: patients' needs and experiences in the course of breast cancer treatment. Patient Educ Couns 2008b; 71(1): 79-85.

[25] Boivin A, Legare F, Gagnon MP. Competing norms: Canadian rural family physicians' perceptions of clinical practice guidelines and shared decision-making. J Health Serv Res Policy 2008; 13(2): 79-84.

[26] Heisler M, Vijan S, Anderson RM, Ubel PA, Bernstein SJ, Hofer TP. When do patients and their physicians agree on diabetes treatment goals and strategies, and what difference does it make? J Gen Intern Med 2003; 18(11): 893-902.

[27] Shepherd HL, Tattersall MH, Butow PN. The context influences doctors' support of shared decision-making in cancer care. $\mathrm{Br} \mathrm{J}$ Cancer 2007; 97(1): 6-13.

[28] Schneider HB, Sandholzer H. Shared decision making: evaluation of German medical students' preferences. J Eval Clin Pract 2008; 14(3): 435-8

[29] Joosten EAG, DeFuentes-Merillas L, de Weert GH, Sensky T, van der Staak CPF, de Jong CAJ. Systematic review of the effects of shared decision making on patient satisfaction, treatment adherence and health status. Psychother Psychsom 2008; 77(4): 219-26.

[30] Naik AD, Kallen MA, Walder A, Street R, Jr. Improving hypertension control in diabetes mellitus: the effects of collaborative and proactive health communication. Circulation 2008; 117(11): 1361-8.

[31] Bieber C, Muller KG, Blumenstiel K, Schneider A, Richter A, Wilke S, Hartmann M, Eich W. Long-term effects of a shared decision making intervention on physician-patient interaction and outcome in fibromyalgia: a qualitative and quantitative 1 year follow-up of a randomized controlled trial. Patient Educ Couns 2006; 63(3): 357-66

[32] Corser W, Holmes-Rovner M, Lein C, Gossain V. A shared decision making primary care intervention for type 2 diabetes. Diabetes Educ 2007; 33(4): 700-8.

[33] Edwards A, Elwyn G, Hood K, et al. Shared decision making study group. Patient-based outcome results from a cluster randomized trial of shared decision making skill development and use of risk communication aids in general practice. Fam Pract 2004; 21(4): 347-54

[34] Ewlyn G, Edwards A, Hood K, et al. Achieving involvement: process outcomes from a cluster randomized trial of shared decision making skill development and use of risk communication aids in general practice. Fam Pract 2004; 21(4): 337-46.

[35] Loh A, Simon D, Wills CE, Kriston L, Niebling W, Harter M. The effects of a shared decision-making intervention in primary care of depression: a cluster-randomized controlled trial. Patient Educ Couns 2007; 67(3): 324-32.

[36] Muller KG, Richter A, Bieber C, Blumenstiel K, Wilke S, Hochlehnert A. The process of shared decision making in chronic pain patients: evaluation and modification of treatment decisions. [Der Prozess der partizipativen Entscheidungsfindung be chronischen Schmerzpatienten. Evaluation und Modifikation von Therapieentscheidungen] Zeitschrift Fur Arztliche Fortbildung Und Qualitatssicherung : In Zusammenarbeit Mit Der KaiserinFriedrich-Stiftung Fur Das Arztliche Fortbildungswese 2004; 98(2): 95-100.

[37] Nielsen-Bohlman L, Panzer AM. Health literacy: a prescription to end confusion. Washington DC: National Academies Press 2004.

[38] Rutland CM. Handheld technology to improve patient care: evaluating a support system for preference-based care planning at the bedside. J Am Med Inform Assoc 2002; 9(2):192-201.

[39] Beach C, Meredith LS, Halpern J, Wells KB, Ford DE. Physician conceptions of loyalty to patients and social justice in healthcare. Rand Health 2005; 3: 53-9.

[40] Moret L, Rochedreux A, Chevalier S, Lombrail P, Gasquet I. Medical information delivered to patients: descrepancies concerning roles as perceived by physicians and nurses set against patient satisfaction. Patient Educ Couns 2008; 70(1): 94-101. 
[41] Iacono MV. Nurses: Trusted patient advocates. J Perianesth Nurs 2007; 22(5): 330-4.

[42] Weaver TE. Enhancing multiple disciplinary teamwork. Nurs Outlook 2008; 56(3): 108-14.

[43] Schwartzberg JG, VanGeest J, Wang C. Understanding health literacy: implications for medicine and public health. Chicago, IL: American Medical Association Bookstore 2005.
[44] Wensing M, Elwyn G, Edwards A, Vingerhoets E \& Grol R. Deconstructing patient centered communication and uncovering shared decision making: an observational study. BMC Med Inform Decis Making 2002; 2: 2.

(C) Clark et al.; Licensee Bentham Open .

This is an open access article licensed under the terms of the Creative Commons Attribution Non-Commercial License (http://creativecommons.org/licenses/by$\mathrm{nc} / 3.0 /$ ) which permits unrestricted, non-commercial use, distribution and reproduction in any medium, provided the work is properly cited. 